\title{
Differential effects of systemically administered nor-binaltorphimine (nor-BNI) on k-opioid agonists in the mouse writhing assay
}

\author{
Jillian H. Broadbear ${ }^{1}$, S. Stevens Negus ${ }^{1}$, Eduardo R. Butelman ${ }^{1}$, Brian R. de Costa ${ }^{3}$, James H. Woods ${ }^{1,2}$ \\ ${ }^{1}$ Department of Pharmacology, University of Michigan, Ann Arbor, MI 48109, USA. \\ ${ }^{2}$ Department of Psychology, University of Michigan, Ann Arbor, MI 48109, USA \\ ${ }^{3}$ NIH-NIDDK, Bethesda, MD 20892, USA
}

Received: 4 August 1993 / Final version: 22 November 1993

\begin{abstract}
The opioid antagonist effects of systemically administered nor-binaltorphimine (nor-BNI) were evaluated against the kappa agonists CI-977, U69,593, U50,488, ethylketocyclazocine (EKC), Mr2034 and bremazocine, the mu agonist morphine and the alkaloid delta agonist BW-373U86 in the acetic acid-induced writhing assay in mice. All eight agonists completely and dose-dependently inhibited writhing. Antagonism of CI977 was apparent $1 \mathrm{~h}$ after administration of $32 \mathrm{mg} / \mathrm{kg}$ nor-BNI, peaking after $4 \mathrm{~h}$ and was maintained for at least 4 weeks; no antagonist effects of nor-BNI were apparent after 8 weeks. Nor-BNI $(32 \mathrm{mg} / \mathrm{kg})$ caused little or no antagonism of morphine or BW-373U86 at $1 \mathrm{~h}$ and none at $24 \mathrm{~h}$ after nor-BNI administration. Subsequently, doseeffect curves for CI-977, U50,488, U69,593, EKC, Mr2034 and bremazocine were determined $24 \mathrm{~h}$ after pretreatment with $3.2,10$ and $32 \mathrm{mg} / \mathrm{kg}$ nor-BNI. Pretreatment with $3.2 \mathrm{mg} / \mathrm{kg}$ nor-BNI produced significant antagonism of all six kappa agonists, suggesting that their antinociceptive effects were mediated at least in part by nor-BNI-sensitive kappa receptors. At higher doses, nor-BNI dose-dependently shifted the agonist dose-effect curves of Cl-977, $\mathrm{U} 50,488, \mathrm{U} 69,593$ and bremazocine, but not those of EKC and $\mathrm{Mr} 2034$, suggesting that the latter compounds may be producing effects via nor-BNI-insensitive receptors. $\mathrm{Mu}$ receptor involvement was demonstrated following a $24 \mathrm{~h}$ pretreatment with $32 \mathrm{mg} / \mathrm{kg} \beta$-FNA in combination with nor-BNI, which significantly increased the degree of antagonism of Mr2034 and EKC from that seen with norBNI alone. Hence, SC administered nor-BNI selectively
\end{abstract}

A preliminary report of these findings was made at the International Narcotic/Research/Conference in Keystone, CO, June, 1992. This work was supported by USPHS grant DA 00254 . Animals used in these studies were maintained in accordance with the University Committee on Use and Care of Animals, University of Michigan, and guidelines of the Committee on Care and Use of Laboratory Animal Resources, National Research Council (Department of Health, Education and Welfare, Publication No. (NIH) 85-23, revised 1983)

Correspondence to : J. H. Broadbear antagonized agonist activity mediated through kappaopioid receptors without differentiating between kappa subtypes. Nor-BNI also enabled the mu agonist activity of proposed kappa agonists to be measured.

Key words: Nor-binaltorphimine - CI-977 - U69,593 - U50,488 - Bremazocine - Ethylketocyclazocine - Mr2034 - Morphine - BW-373U86 - $\beta$-Funaltrexamine - Kappa antagonists - Acetic acid-induced writhing - Mice

There is much experimental evidence supporting the premise that opioid effects are mediated by at least three opioid receptor types: mu and kappa (Martin et al 1976) and delta (Lord et al. 1977). Subsequent studies have highlighted some heterogeneity in the receptors within these opioid types, and further subdivisions of the mu (Pasternak 1986; Rothman et al. 1991), kappa (Zukin et al. 1988; Clark et al. 1989; Devlin and Shoemaker 1990; Rothman et al. 1990) and delta (Jiang et al. 1991; Sofuoglu et al. 1991) receptor types have been proposed.

The development of selective opioid antagonists has played a critical role in distinguishing among receptor types. For instance, $\beta$-funaltrexamine (Portoghese et al. 1980) and naltrindole (Portoghese et al. 1988) have been characterized as mu- and delta- receptor antagonists respectively. Nor-binaltorphimine (nor-BNI) has been proposed as a kappa-selective antagonist (Portoghese et al. 1987; Takemori et al. 1988a). It has since been demonstrated that nor-BNI is a selective, systemically active and reversible kappa antagonist with a slow onset and a long duration of action of up to 8 weeks (Endoh et al. 1992; Horan et al. 1992; Jones and Holtzman 1992; Butelman et al. 1993).

Kappa receptors are of special interest as they mediate antinociceptive effects without the side effects of respiratory depression and high abuse potential that limit the clinical utility of mu agonists. Kappa receptors have been implicated as important mediators in the control of water 
balance (Cooper and Sanger 1984), food intake (Cooper et al. 1985), antinociception (Schmauss and Yaksh 1984), discriminative stimulus effects (e.g. Hein et al. 1981) and sedation (Martin et al. 1976). The use of in vitro techniques that employ radio-labeled ligands in rodent brain homogenates has identified receptor subtypes to which kappa-selective ligands bind with differential affinity, enabling some preliminary characterization of kappa receptor subtypes (Zukin et al. 1988; Clark et al. 1989; Devlin and Shoemaker 1990; Rothman et al. 1990). The first physiological evidence for kappa receptor heterogeneity was demonstrated using the opioid antagonist quadazocine (WIN 44441-3), which antagonized the effects of tifluadom and ethylketocyclazocine (EKC) on plasma corticosterone and TSH levels, but not those of Mr2034 or U50,488 (Iyengar et al. 1986). Recent in vivo work in mice reported differential antagonism of kappa agonists using (-)-UPHIT, a selective, non-equilibrium kappa antagonist, and suggested that this was due to heterogeneity among kappa receptors (Horan et al. 1991).

Several studies have indicated that nor-BNI may also be useful in differentiating between kappa agonists, perhaps on the basis of kappa receptor subtypes. Some in vitro binding studies indicate that nor-BNI differs in its affinity for various kappa receptor subtypes (Rothman et al. 1988; Clark et al. 1989), and in the guinea pig ileum assay, norBNI was shown to be a more potent antagonist of U50,488 than of EKC (Portoghese et al. 1987). In vivo work examining the effect of systemic nor-BNI administration on diuresis produced by kappa agonists in rats showed that norBNI was a more effective antagonist of both U50,488 and bremazocine-induced diuresis than of EKC-induced diuresis (Takemori et al. 1988b). Recent studies in our laboratory involving rhesus monkeys in the warm water tailwithdrawal assay showed that systemically administered nor-BNI antagonized the antinociceptive effects of U69,593 and U50,488 but had no effect on CI-977, bremazocine, Mr2033 or EKC (Butelman et al. 1993). Studies where norBNI was administered to mice are somewhat ambiguous with respect to whether or not kappa agonists are differentially antagonized by nor-BNI (Takemori et al. 1988a; Horan et al. 1992). These inconsistent findings may be a reflection of differences in kappa opioid pharmacology in mice relative to other species (particularly primates), or of procedural differences across studies. To date, no one study has set out to evaluate the antagonist effects of nor-BNI across a range of kappa agonists in mice.

Accordingly, the purpose of the present study was to conduct a detailed examination of the potency with which nor-BNI antagonizes a wide range of kappa agonists, and thus explore the hypothesis that kappa agonists will differ in their sensitivity to nor-BNI when administered to mice, as has been reported in other species. If the results support this hypothesis, the existence of a subset(s) of kappa receptors at which nor-BNI has less affinity may be indicated. Alternatively, it may be possible to demonstrate that some kappa agonists have activity at non-kappa sites under these experimental conditions. This study will endeavor to discern which if either of these alternatives provides the best explanation.

Initially, the time course of the kappa, mu and delta opioid antagonist effects of systemically administered nor-
BNI was evaluated against the highly selective kappa agonist CI-977 (Hunter et al. 1990), the mu agonist morphine (Martin et al. 1976) and the delta agonist, BW373 U86 (Comer 1992; Chang et al. 1994). Subsequently, the present study examined the ability of systemically administered nor-BNI to selectively antagonize the effects of a series of kappa agonists including the arylacetamides CI-977, U50,488 (Von Voigtlander et al. 1982) and U69,593 (Lahti et al. 1985), and the benzomorphans EKC (Martin et al. 1976), bremazocine (Romer et al. 1980) and Mr2034 (Merz et al. 1975). A role for mu receptors in mediating the antinociceptive effects of some kappa agonists was evaluated using the selective and irreversible mu antagonist $\beta$-funaltrexamine ( $\beta$-FNA; Ward et al. 1982).

\section{Materials and methods}

Animals. Male NIH mice (18-32 g, Harlan Sprague-Dawley, Indianapolis, Ind.) were housed $8-12$ per cage at approximately $22^{\circ} \mathrm{C}$ on a 12-h light/dark cycle. Food and water were available ad libitum until testing. Each animal was used only once.

Test of antinociception. The acetic acid-induced writhing assay (Koster et al. 1959), as modified for use in this laboratory (Comer 1992), was used to determine the degree of antinociception. Brieffy, mice received an IP injection of $0.6 \%$ acetic acid $(0.4 \mathrm{ml} /$ animal $)$ and were placed in individual Plexiglas boxes $(18 \times 28 \times 13 \mathrm{~cm})$ for observation. Five minutes after the acetic acid injection was given, a 5-min observation period was initiated during which time the number of writhes, typically a wave of contraction of the abdominal musculature followed by extension of the hind legs, was recorded. Vehicle or test drugs were administered at various times prior to the administration of acetic acid, as detailed below.

Effects of nor-BNI alone. The agonist effects of sterile water, 10 and $32 \mathrm{mg} / \mathrm{kg}$ nor-BNI were tested by administering sterile water or nor-BNI SC at $5,10,15,30,45,60,75$ and $90 \mathrm{~min}$ as well as $24 \mathrm{~h}$ prior to the administration of acid. Higher doses of nor-BNI were not investigated because it was found that they caused local irritation for several hours, with subsequent visible tissue damage at the site of injection.

Time course of the antagonist effects of nor-BNI. Since $32 \mathrm{mg} / \mathrm{kg}$ nor-BNI was the highest dose that could be safely administered, the next phase of experiments examined the time course of the kappa, $\mathrm{mu}$ and delta antagonist effects of $32 \mathrm{mg} / \mathrm{kg}$ nor-BNI. This was evaluated against $\mathrm{Cl}-977 \quad(0.01-1.0 \mathrm{mg} / \mathrm{kg})$, morphine $(0.1-3.2 \mathrm{mg} / \mathrm{kg})$ and $\mathrm{BW}-373 \mathrm{U} 86(0.32-32 \mathrm{mg} / \mathrm{kg})$, respectively, with baseline agonist dose-effect curves determined by administering each agonist $15 \mathrm{~min}$ prior to the administration of acetic acid. The dose-effect curves for CI-977, morphine and BW-373U86 were then determined by administering the agonist $1 \mathrm{~h}$ and $24 \mathrm{~h}$ after the administration of $32 \mathrm{mg} / \mathrm{kg}$ nor-BNI. A more complete time course of antagonism was obtained with CI-977 by determining the CI-977 dose-effect curve $4 \mathrm{hr}, 2,4,7,28$ and 56 days after nor-BNI. Each observation point was determined using a different group of mice.

Selectivity of kappa antagonist effects of nor-BNI. Since the time course evaluation indicated that the peak antagonist effects of norBNI were sustained from $4 \mathrm{~h}$ to 4 weeks after its administration, subsequent studies employed a $24 \mathrm{~h}$ pretreatment time. The sensitivity of kappa agonists to antagonism by nor-BNI was evaluated using the following kappa agonists; CI-977 (0.01-1.0 mg/kg), U50,488 $(1.0-100 \mathrm{mg} / \mathrm{kg}), U 69,593(0.1-10 \mathrm{mg} / \mathrm{kg})$, EKC $(0.032-1.0 \mathrm{mg} / \mathrm{kg})$, bremazocine $(0.0032-3.2 \mathrm{mg} / \mathrm{kg})$ and $\mathrm{Mr} 2034(0.0032-0.32 \mathrm{mg} / \mathrm{kg})$. Baseline dose-effect curves for each agonist were determined as described above. Dose-effect curves for each agonist were then 
determined again $24 \mathrm{~h}$ after pretreatment with $3.2,10$ and $32 \mathrm{mg} / \mathrm{kg}$ nor-BNI.

Antagonist effects of $\beta$-funaltrexamine. Since nor-BNI did not produce a dose-dependent antagonism of EKC or Mr2034, we evaluated the possible role of mu receptors in the antinociceptive effects of these agonists using the mu-selective and irreversible antagonist $\beta$-FNA. We then compared the agonist dose-effect curves for EKC and Mr2034 under the following four conditions: 1) agonist alone, 2) $24 \mathrm{~h}$ after pretreatment with $32 \mathrm{mg} / \mathrm{kg}$ nor-BNI, 3) $24 \mathrm{~h}$ after pretreatment with $32 \mathrm{mg} / \mathrm{kg} \beta$-FNA, and 4) $24 \mathrm{~h}$ after pretreatment with both $32 \mathrm{mg} / \mathrm{kg} \beta$-FNA and $32 \mathrm{mg} / \mathrm{kg}$ nor-BNI. By way of comparison, the antagonist effects of nor-BNI, $\beta$-FNA and the $\beta$-FNA/nor-BNI combination were evaluated against CI-977, U69,593, morphine and BW-373U86. The $32 \mathrm{mg} / \mathrm{kg}$ dose and $24-\mathrm{h}$ pretreatment time for $\beta$-FNA were used on the basis of preliminary experiments, indicating that under these conditions, $\beta$-FNA did not produce agonist effects but did antagonize the effects of morphine (Ward et al. 1982).

Chenicals. The compounds used in this study were: nor-BNI (B. de Costa, NIDDK, National Institutes of Health, Bethesda, Md.), $\beta$-FNA (D. Zimmerman, Eli Lilly, Indianapolis, Ind), CI-977 (Parke-Davis, Ann Arbor, Mich.), U50,488 and U69,593 (Upjohn, Kalamazoo, Mich.), EKC (National Institute on Drug Abuse, Rockville, Md), bremazocine (Sandoz, Basel, Switzerland), Mr2034 (Boehringer Ingelheim, Ingelheim am Rhein, Germany), morphine sulfate (Mallinkrodt, St Louis, Mo.) and BW-373U86 $\left(( \pm)-4-\left(\left(R^{*}\right)-\alpha-\left(\left(2 S^{*} 5 R^{*}\right)-4-\right.\right.\right.$ Allyl-2,5-dimethyl-1-piperazinal $)-3-$ hydroxybenzyl)- $N, N$-diethylbenzamide dihydrochloride; Burroughs Wellcome, Research Triangle Park, N.C.). All compounds were dissolved in sterile water and were administered in volumes of $0.01 \mathrm{ml} / \mathrm{g}$ SC. CI-977, U50,488, U69,593, bremazocine, EKC, Mr2034, morphine and BW-373U86 were all administered $15 \mathrm{~min}$ prior to acid in the present study on the basis of preliminary studies indicating that all eight compounds produced peak effects at this pretreatment time. Glacial acetic acid was purchased from Fisher Scientific Co., Fair Lawn, N.J. and the $0.6 \%$ solution was made using sterile water

Data analysis. Each treatment group consisted of six mice, and each mouse was used for only one treatment. The control number of writhes per mouse was defined as the mean number of writhes per mouse when a SC injection of sterile water was given 15 min prior to the acetic acid injection. The value of the control was found to vary somewhat between batches of mice and thus was routinely redetermined for each new batch (generally once a week). For treatment groups, the number of writhes for each mouse was expressed as percent of the control number of writhes per mouse. The percent control values for the mice in the treatment group were then averaged and the SEM calculated. $\mathrm{A}_{50}$ values and $95 \%$ confidence limits were determined for each agonist administered alone and after pretreatment with nor-BNI according to the method of Tallarida and Murray (1981. procedure 8), with the $\mathrm{A}_{30}$ defined as the dose of agonist reducing writhing to $50 \%$ of control. Dose-effect curves were considered to be significantly different when the range of values contained within the $95 \%$ confidence limits did not overlap. The time course of the effects of nor-BNI when administered alone was analyzed using analysis of variance with two between subjects variables; dose and time.

\section{Results}

\section{Control values}

Mean control values across batches of mice ranged from $11.3 \pm 2.6$ to $16.3 \pm 1.7$ writhes per mouse. The IP administration of $0.4 \mathrm{ml}$ sterile water alone did not induce writhing. Furthermore, the effects of nor-BNI alone (10 and
$32 \mathrm{mg} / \mathrm{kg}$ ) were no different than the effects of sterile water on acetic acid-induced writhing $(P>0.05)$.

\section{Agonist effects}

The dose-effect curves for the kappa agonists CI-977, U69,593, U50,488, EKC, Mr2034 and bremazocine, the mu agonist morphine and the delta agonist BW-373U86 are displayed in Figs 1-3. All eight compounds produced a dose-dependent and complete suppression of writhing. Tables 1 and 2 show the $A_{50}$ values for each drug administered alone. The relative potencies of the kappa agonists were $\quad$ bremazocine $\geq$ CI-977 $\geq \mathrm{Mr} 2034>$ EKC $>$ U69,593 > U50,488. Morphine was slightly more potent than U50,488, and BW-373U86 was slightly less potent than $\mathrm{U} 50,488$.

\section{Time course of the antagonist effects of nor-BNI}

Figure 1 shows the time course of the antagonism of CI- 977 by $32 \mathrm{mg} / \mathrm{kg}$ nor-BNI, and Table 1 shows the $\mathrm{A}_{50}$ values for CI-977 at the various times after nor-BNI pretreatment. One-hour pretreatment with $32 \mathrm{mg} / \mathrm{kg}$ norBNI produced a rightward, parallel shift in the CI-977 dose-effect curve and a 2.9 -fold increase in the $\mathrm{A}_{50}$. After a 4 -h pretreatment with $32 \mathrm{mg} / \mathrm{kg}$ nor-BNI, the $\mathrm{A}_{50}$ for CI-977 was increased 12-fold. Longer pretreatment times of up to 28 days produced antagonist effects that were similar to the antagonism observed after the 4-h pretreatment (dose ratios ranged from 8 to 19). Following a 56day pretreatment with nor-BNI, the $A_{50}$ for CI-977 was not significantly different from the control $\mathrm{A}_{50}$ for CI-977.

Figure 2 shows the time course of the antagonism of morphine and BW-373U 86 by $32 \mathrm{mg} / \mathrm{kg}$ nor-BNI, and Table 1 shows the $A_{50}$ values for morphine and $B W$ 373 U86 at the various times after nor-BNI pretreatment.

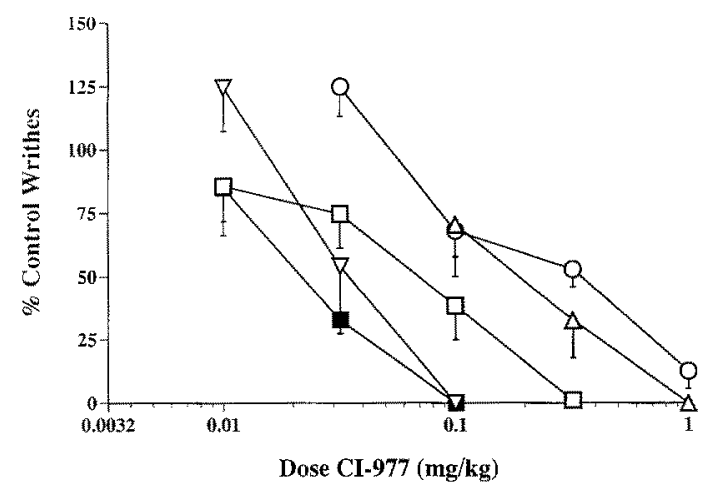

Fig. 1. Time course of the antagonist effects of $32 \mathrm{mg} / \mathrm{kg}$ nor-BNI in combination with the kappa agonist CI-977. Abscissa in this and all subsequent graphs: dose agonist in $\mathrm{mg} / \mathrm{kg}(\log$ scale). Ordinate in this and all subsequent graphs: \% of control number of writhes per mouse. This figure shows the effects of nor-BNI administered $1 \mathrm{~h}$, $4 \mathrm{~h}, 4$ weeks and 8 weeks prior to administration of CI-977. Each point in this and all subsequent graphs represents the mean data. from 5-6 mice. $\mathbf{v}$, CI-977 alone; $\square$, + nor-BNI ( 1 h ptt); $\bigcirc+$ norBNI ( $4 \mathrm{~h}$ ptt); $\triangle,+$ nor-BNI $(4$ wk ptt); $\nabla,+$ nor-BNI $(8$ wk ptt) 

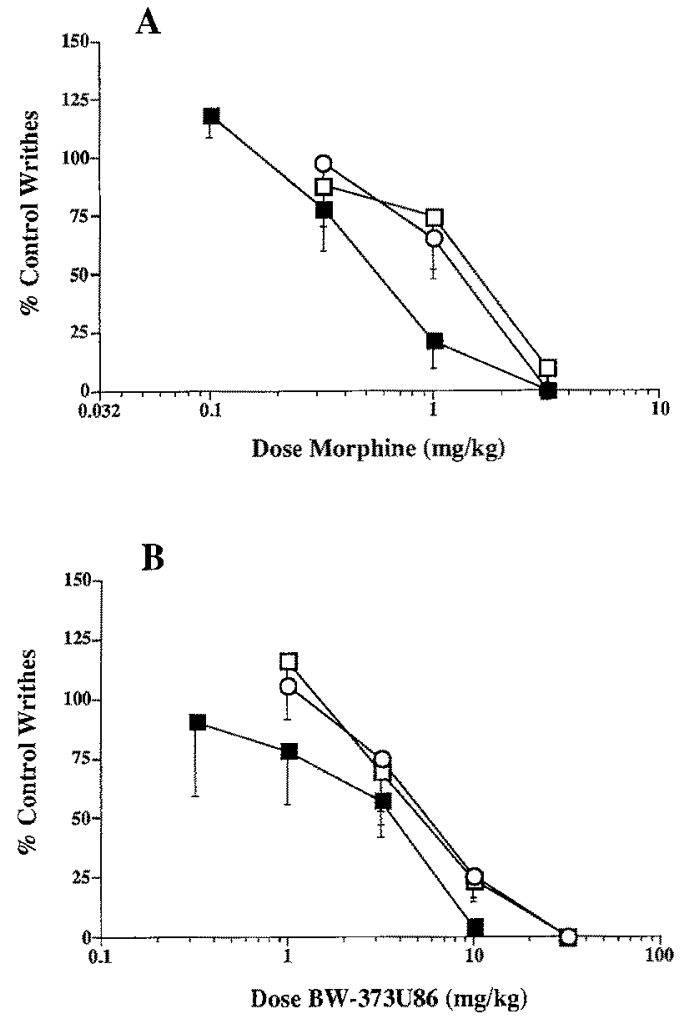

Fig. 2. Time course of the antagonist effects of $32 \mathrm{mg} / \mathrm{kg}$ nor-BNI administered 1 and $24 \mathrm{~h}$ prior to the administration of the mu agonist morphine (A) or the delta agonist BW-373U86 (B). $\mathbf{E}$, agonist alone, $\square,+$ nor-BNI $(32 \mathrm{mg} / \mathrm{kg}-1 \mathrm{~h} \mathrm{ptt}) ; 0$, + not-BNI (32 $\mathrm{mg} / \mathrm{kg}-24 \mathrm{~h} \mathrm{ptt)}$

One-hour pretreatment with $32 \mathrm{mg} / \mathrm{kg}$ nor-BNI also produced a parallel rightward shift in the dose-effect curve for morphine and a small but significant 2.2-fold increase in the morphine $A_{50}$. Twenty-four hour pretreatment with nor-BNI produced less of a shift in the morphine doseeffect curve, and the $\mathrm{A}_{50}$ for morphine no longer differed significantly from its baseline value (Horan et al. 1991; Endoh et al. 1992). Neither 1-h nor 24-h pretreatment with $32 \mathrm{mg} / \mathrm{kg}$ nor-BNI significantly affected the BW373 U86 dose-effect curve.

\section{Selectivity of the kappa antagonist effects of nor-BNI}

Figure 3 shows the effects of CI-977, U50,488, U69,593, bremazocine, EKC and Mr2034 alone and in combination with $3.2,10$ and $32 \mathrm{mg} / \mathrm{kg}$ nor-BNI given $24 \mathrm{~h}$ previously. Table 2 shows the $A_{50}$ values for each agonist alone and following nor-BNI pretreatment. Nor-BNI produced parallel rightward shifts and significant increases in $A_{50}$ values for all six kappa agonists; however, the pattern of antagonism differed across agonists. A dose of $3.2 \mathrm{mg} / \mathrm{kg}$ nor-BNI produced rightward shifts and increases in agonist $A_{50}$ values of comparable magnitude for all six agonists, with dose ratios ranging from a low of 1.6 for EKC to a high of 3.8 for bremazocine. The magnitude of the increase in $\mathrm{A}_{50}$ value produced by $3.2 \mathrm{mg} / \mathrm{kg}$ nor-BNI was statistically significant for every agonist except EKC. In contrast to the similar effects produced by $3.2 \mathrm{mg} / \mathrm{kg}$ norBNI, the magnitude of the rightward shifts obtained with higher doses of nor-BNI differed dramatically across the different agonists. For example, $32 \mathrm{mg} / \mathrm{kg}$ nor-BNI produced a 73 -fold increase in the bremazocine $A_{50}$, but only a 3.8-fold increase in the Mr2034 $\mathrm{A}_{50}$. Thus, although each of these agonists displayed a similar sensitivity to the antagonist effect of the low dose of nor-BNI $(3.2 \mathrm{mg} / \mathrm{kg})$, there was considerable variation in the ability of higher doses of nor-BNI (10 and $32 \mathrm{mg} / \mathrm{kg}$ ) to produce additional rightward shifts in these agonist dose-effect curves.

\section{Antagonist effects of $\beta-F N A$}

Table 3 compares the effects of 24 -h pretreatment with 1 ) $32 \mathrm{mg} / \mathrm{kg}$ nor-BNI, 2) $32 \mathrm{mg} / \mathrm{kg} \beta$-FNA or 3) norBNI $+\beta$-FNA on dose-effect curves for CI-977, U69,593, BW-373U86, morphine, EKC and Mr2034. Pretreatment with nor-BNI produced a significant increase in the $\mathrm{A}_{50} \mathrm{~S}$ for CI-977 and U69,593, but pretreatment with $\beta$-FNA
Table 1. $\mathrm{A}_{50}$ values in $\mathrm{mg} / \mathrm{kg}$ and dose ratios for the kappa agonist CI-977, the mu agonist morphine and the delta agonist BW-373U86 alone and at various times after the administration of $32 \mathrm{mg} / \mathrm{kg}$ norBNI. The $95 \%$ confidence limits of the $A_{50}$ values are given in parentheses

\begin{tabular}{llll}
\hline Agonist & $\begin{array}{l}\text { Nor-BNI } \\
\text { Pretreatment time }\end{array}$ & A $_{50}(95 \% \mathrm{CL})$ & Dose ratió \\
\hline CI-977 & Alone & $0.024(0.018-0.031)$ & - \\
& $1 \mathrm{~h}$ & $0.070(0.045-0.11)^{*}$ & 2.9 \\
& $4 \mathrm{~h}$ & $0.28(0.18-0.44)^{*}$ & 12 \\
& $24 \mathrm{~h}$ & $0.20(0.12-0.33)^{*}$ & 8.3 \\
& 4 days & $0.45(0.33-0.68)^{*}$ & 19 \\
& 7 days & $0.37(0.30-0.45)^{*}$ & 15 \\
& 28 days & $0.20(0.12-0.32)^{*}$ & 8.0 \\
Morphine & 56 days & $0.038(0.027-0.053)$ & 1.6 \\
& Alone & $0.55(0.40-0.77)$ & - \\
& $1 \mathrm{~h}$ & $1.2(0.85-1.6)^{*}$ & 2.2 \\
BW-373U86 & $24 \mathrm{~h}$ & $1.1(0.71-1.7)$ & 2.0 \\
& Alone & $3.7(2.4-5.8)$ & 1.4 \\
& $1 \mathrm{~h}$ & $5.2(3.2-8.4)$ & 1.5 \\
\hline
\end{tabular}

* Indicates $A_{50}$ values significantly different from $A_{50}$ value for agonist alone 
$\mathbf{A}$
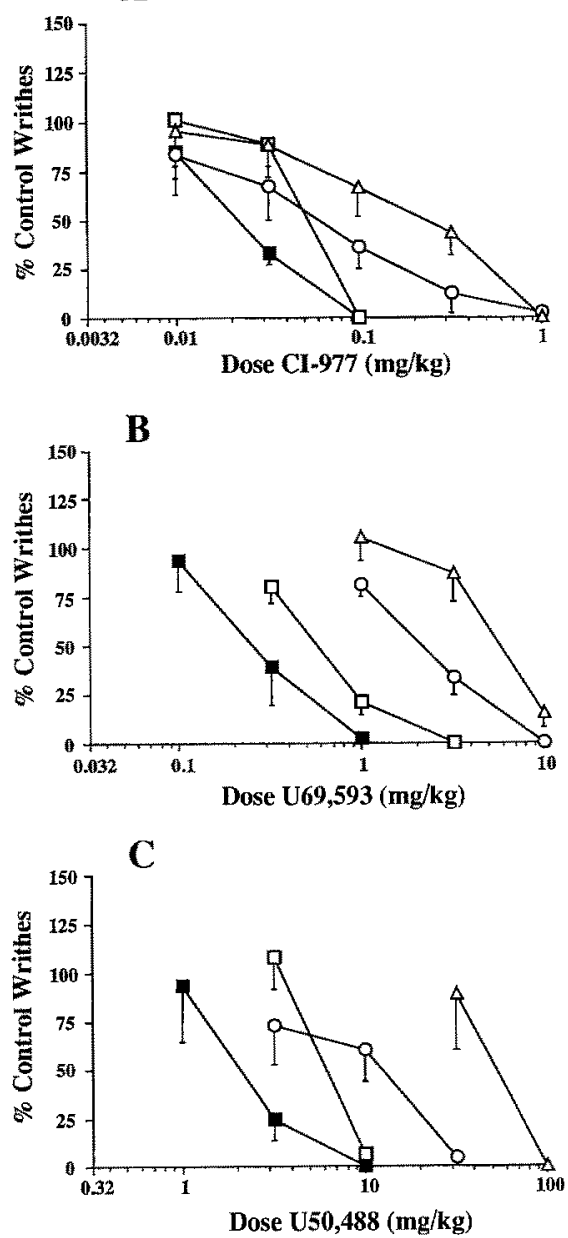

Fig. 3. Antagonist effects of $3.2,10$ and $32 \mathrm{mg} / \mathrm{kg}$ nor-BNI administered $24 \mathrm{~h}$ prior to the administration of the arylacetamide kappa agonists CI-977 (A), U69,593 (B) and U50,488 (C) and the ben-

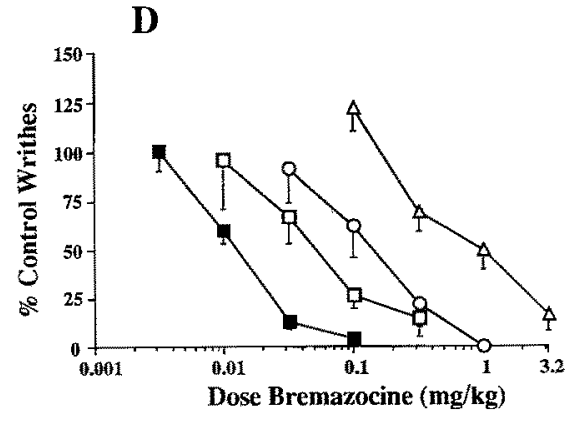

E

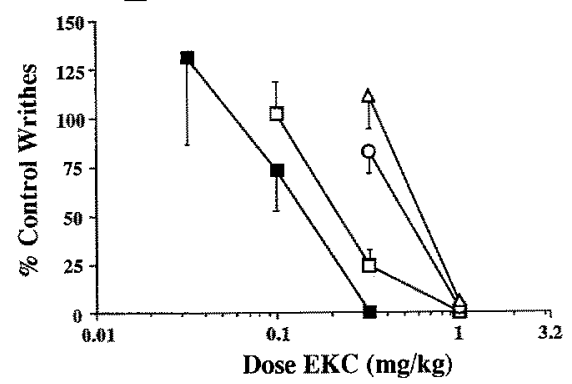

F

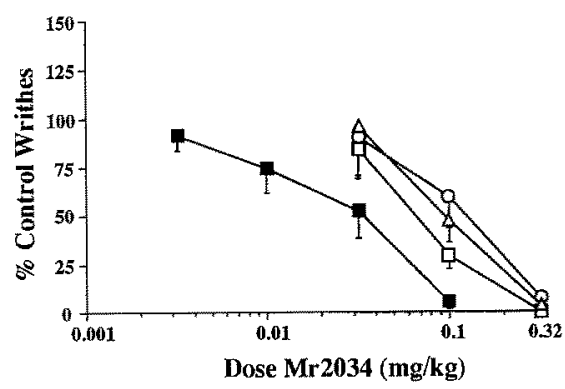

zomorphan kappa agonists bremazocine (D), EKC (E) and Mr2034 (F). $\mathbf{\square}$, agonist alone; $\square+$ nor-BNI $(3.2 \mathrm{mg} / \mathrm{kg}) ; 0$, + nor-BNI $(10 \mathrm{mg} / \mathrm{kg}) ; \triangle,+$ nor-BNI $(32 \mathrm{mg} / \mathrm{kg})$

had no effect, and pretreatment with nor-BNI $+\beta$-FNA was no more effective that nor-BNI alone. For morphine, pretreatment with $\beta$-FNA produced a significant increase in the $A_{50}$, but prior administration of nor-BNI had no effect, and pretreatment with nor-BNI $+\beta$-FNA was no more effective than pretreatment with $\beta$-FNA alone. None of the nor-BNI or $\beta$-FNA pretreatments had any affect on the $\mathrm{A}_{50}$ for $\mathrm{BW}-373 \mathrm{U} 86$.

In contrast to the selective effects of nor-BNI and $\beta$-FNA on CI-977, U69,593, morphine and BW$373 \mathrm{U} 86$, both nor-BNI and $\beta$-FNA antagonist effects on Mr2034 and EKC. For Mr2034, the pretreatment with nor-BNI alone and $\beta$-FNA alone produced significant increases in the $A_{50}$ for Mr2034. Furthermore, pretreatment with nor-BNI $+\beta$-FNA produced a greater increase in the $A_{50}$ for $\mathrm{Mr} 2034$ and did either antagonist alone. For EKC, pretreatment with nor-BNI alone produced a significant increase in the $A_{50}$, whereas pretreatment with $\beta$-FNA alone was without effect. However, pretreatment with nor-BNI $+\beta$-FNA produced a larger increase in the $A_{50}$ for EKC than did nor-BNI alone.

\section{Discussion}

The kappa opioid agonists CI-977, U69,593, U50,488, bremazocine, EKC and Mr2034 as well as the mu-selective agonist morphine and the delta against BW-373U86, were fully effective in the writhing assay, each producing a dose-dependent suppression of the writhing response. The order of potency of the kappa agonists was: bremazocine $\geq \mathrm{CI}-977 \geq \mathrm{Mr} 2034>\mathrm{EKC}>\mathrm{U} 69,593>$ U50,488. Morphine was slightly more potent than U50,488, and BW-373U86 less potent than U50,488. Previous studies have reported similar relative potencies for these compounds in producing antinociception in the mouse acetic acid-induced writhing assay as well as in other procedures in mice and rats (Leander 1984; Hayes and Kelly 1987a; Hunter et al. 1990; Comer 1992).

In the present study, nor-BNI produced kappa antagonist effects with slow onset and extremely long duration of action (on the order of weeks). In addition, nor-BNI produced small mu antagonist effects which were significant at $1 \mathrm{~h}$ (Endoh et al. 1992). Nor-BNI did not antagonize the antinociceptive effects of BW-373U86 after either 
Table 2. $\mathrm{A}_{50}$ values in $\mathrm{mg} / \mathrm{kg}$ and dose ratios for Cl-977, U50,488, U69,593, bremazocine, EKC and Mr2034 alone and $24 \mathrm{~h}$ after pretreatment with $3.2,10$ or $32 \mathrm{mg} / \mathrm{kg}$ nor-BNI. The $95 \%$ confidence limits of the $A_{50}$ values are given in parentheses

\begin{tabular}{llll}
\hline Agonist & $\begin{array}{l}\text { Dose nor-BNI } \\
(\mathrm{mg} / \mathrm{kg})\end{array}$ & $\mathrm{A}_{50}(95 \% \mathrm{CL})$ & Dose ratio \\
\hline CI-977 & Alone & $0.024(0.018-0.031)$ & - \\
& 3.2 & $0.053(0.045-0.62)^{*}$ & 2.2 \\
& 10 & $0.056(0.026-0.12)$ & 2.3 \\
U50,488 & 32 & $0.20(0.12-0.33)^{*}$ & 8.3 \\
& Alone & $1.8(1.0-3.1)$ & - \\
& 3.2 & $6.1(5.1-7.4)^{*}$ & 3.4 \\
U69,593 & 10 & $12(7.9-19)^{*}$ & 6.7 \\
& 32 & $52(35-80)^{*}$ & - \\
& Alone & $0.24(0.17-0.35)$ & 2.6 \\
Bremazocine & 3.2 & $0.63(0.48-0.83)^{*}$ & 9.6 \\
& 10 & $2.3(1.8-2.9)^{*}$ & - \\
& 32 & $5.1(3.4-7.9)^{*}$ & 3.8 \\
& Alone & $0.012(0.0090-0.015)$ & 11 \\
EKC & 3.2 & $0.046(0.022-0.097)^{*}$ & 73 \\
& 10 & $0.13(0.080-0.22)^{*}$ & - \\
& 32 & $0.88(0.60-1.3)^{*}$ & 1.6 \\
& Alone & $0.14(0.078-0.24)$ & 3.6 \\
Mr2034 & 3.2 & $0.22(0.16-0.29)$ & 4.8 \\
& 10 & $0.51(0.42-0.62)^{*}$ & - \\
& 32 & $0.67(0.54-0.82)^{*}$ & 3.8 \\
\hline & Alone & $0.026(0.016-0.042)$ & \\
& 3.2 & $0.068(0.049-0.095)^{*}$ & $0.11(0.065-0.17)^{*}$ \\
\hline
\end{tabular}

* Indicates $A_{50}$ values significantly different from $A_{50}$ value for agonist alone

Table 3. $\mathrm{A}_{50}$ values in $\mathrm{mg} / \mathrm{kg}$ for CI-977, U69,593, morphine, BW-373U86, Mr2034 and EKC alone and $24 \mathrm{~h}$ after pretreatment with $32 \mathrm{mg} / \mathrm{kg}$ nor-BNI alone, $32 \mathrm{mg} / \mathrm{kg} \beta$-FNA alone or a combination of $32 \mathrm{mg} / \mathrm{kg}$ nor-BNI $+32 \mathrm{mg} / \mathrm{kg} \beta$-FNA. The $95 \%$ confidence limits of the $A_{50}$ values are shown in parentheses

\begin{tabular}{lllll}
\hline Agonist & Agonist alone & + nor-BNI & $+\beta$-FNA & + nor-BNI and $\beta$-FNA \\
\hline CI-977 & $0.024(0.018-0.031)$ & $0.20(0.12-0.33)^{*}$ & $0.019(0.015-0.024)$ & $0.38(0.25-0.58)^{*}$ \\
U69,593 & $0.24(0.17-0.35)$ & $5.1(3.4-7.9)^{*}$ & $0.31(0.24-0.41)$ & $7.2(4.5-11)^{*}$ \\
Morphine & $0.61(0.45-0.84)$ & $1.1(0.71-1.7)$ & $4.0(3.0-5.4)^{*}$ & $5.6(4.4-7.1)^{*}$ \\
BW-373U86 & $3.7(2.4-5.8)$ & $5.4(3.0-9.9)$ & $2.5(1.6-3.7)$ & $7.3(4.8-11)$ \\
Mr2034 & $0.026(0.016-0.042)$ & $0.098(0.077-0.012)^{*}$ & $0.11(0.076-0.16)^{*}$ & $1.0(0.77-1.4)^{*} \oplus$ \\
EKC & $0.14(0.078-0.24)$ & $0.67(0.54-0.82)^{*}$ & $0.16(0.12-0.21)$ & $1.55(1.2-2.1)^{*} \oplus$ \\
\hline
\end{tabular}

a Data taken from Table 2

* Significantly different from agonist alone

Combination significantly different from nor-BNI alone and $\beta$-FNA alone

1- or $24-\mathrm{h}$ pretreatment with nor-BNI. BW-373U86 has been characterized as a novel, systemically-active, alkaloid delta agonist whose antinociceptive effects are potently and selectively antagonized by the delta antagonist naltrindole in the mouse writhing assay (Comer 1992). Thus our finding that nor-BNI pretreatment failed to antagonize the antinociceptive effects of BW-373U86 suggests that nor-BNI did not act as a delta receptor antagonist in the dose range studied.

This profile of nor-BNI agrees with other studies that have characterized the time course and selectivity of the opioid antagonist effects of nor-BNI administered by the same route of administration (SC; Takemori et al. 1988a; Endoh et al. 1992), as well as the ICV route of administration (Takemori et al. 1988a; Horan et al. 1992). For example, Endoh et al. (1992) found that the mu antagonist effects of nor-BNI (as evaluated against morphine) peaked 30-60 min after nor-BNI administration and were no longer detectable after $4 \mathrm{~h}$, and at $24 \mathrm{~h}$ after its administration, nor-BNI displayed highly selective kappa antagonist effects. Our finding that nor-BNI did not antagonize BW373 U86 also agrees with other studies showing that norBNI is either ineffective as a delta antagonist or less potent as a delta antagonist than as a kappa antagonist (Birch et al. 1987; Takemori et al. 1988a,b; Horan et al. 1992).

The present study extended this characterization of nor-BNI by examining in detail the antagonist effects of nor-BNI against a series of arylacetamide and benzomorphan kappa agonists and determining whether different kappa agonists displayed differential sensitivity to antagonism by nor-BNI. These antagonism experiments were conducted $24 \mathrm{~h}$ after pretreatment with nor-BNI. Several 
studies have indicated that, from several hours to several days after its administration, nor-BNI displays peak antagonist effects against several kappa agonists including CI-977 (present study), U50,488 (Endoh et al. 1992), U69,593 and bremazocine (Horan et al. 1991). This suggests that a $24 \mathrm{~h}$ pretreatment time should lie within the time of the peak antagonist effects of nor-BNI. Using this pretreatment time, all six kappa agonists were significantly antagonized by nor-BNI. Furthermore, the kappa agonists displayed similar sensitivity to antagonism by $3.2 \mathrm{mg} / \mathrm{kg}$ nor-BNI after $24 \mathrm{~h}$, with dose-effect curves for five of the six agonists being shifted to the right to a similar and statistically significant degree. Only the EKC dose-effect curve was not shifted to the right to a significant degree by $3.2 \mathrm{mg} / \mathrm{kg}$ nor-BNI, but the EKC doseeffect curve was shifted significantly in the presence of 10 and $32 \mathrm{mg} / \mathrm{kg}$ nor-BNI. These findings suggest that at least some portion of the antinociceptive effects of CI-977, U50,488, U69,593, bremazocine, EKC and Mr2034 was mediated by a similar (nor-BNI sensitive) population of kappa opioid receptors.

Despite these similarities however, the kappa agonists evaluated in the present study displayed dramatically different sensitivity to the antagonist effects of doses of norBNI higher than $3.2 \mathrm{mg} / \mathrm{kg}$. This difference becomes most evident when comparing the antagonist effects of nor-BNI against bremazocine and $\mathrm{Mr} 2034$. Pretreatment with $3.2 \mathrm{mg} / \mathrm{kg}$ nor-BNI produced similar and significant rightward shifts in the dose-effect curves of both bremazocine and Mr2034 as mentioned above (3.8-fold and 2.6-fold, respectively); however, the effect of pretreatment with $32 \mathrm{mg} / \mathrm{kg}$ nor-BNI on the two agonist dose-effect curves differed widely: the bremazocine $\mathrm{A}_{50}$ was increased 73fold relative to control, whereas the $\mathrm{A}_{50}$ for $\mathrm{Mr} 2034$ was increased only 3.8 -fold relative to control. Thus, nor-BNI produced a dose-dependent antagonism of bremazocine, but the higher doses of nor-BNI in combination with Mr2034 were no more effective than the low dose of nor-BNI.

These findings agree with other studies in rodents reporting that the effectiveness of nor-BNI as a kappa antagonist varies across kappa agonists (Takemori et al. 1988a, b), and suggest that some kappa agonists are capable of producing antinociceptive effects in the writhing assay in mice by acting at nor-BNI-insensitive receptors as well as at nor-BNI-sensitive receptors. The first and most likely possibility is that non-kappa receptors, particularly mu opioid receptors, may have contributed to the antinociceptive effects of some of the kappa agonists tested in this study, namely EKC and Mr2034. Binding studies have shown that Mr2034 and EKC each have high affinity for $\mathrm{mu}$ as well as kappa receptors (Wood et al. 1981; Magnan et al. 1982; Hunter et al. 1990). In addition, functional studies have demonstrated that Mr2034 and EKC can function as mu agonists in rodents under some circumstances, indicating that they may have sufficient efficacy at mu receptors to produce mu agonist effects (Hayes et al. 1987b; Zimmerman et al. 1987).

The hypothesis that mu-receptor activation contributed to the antinociceptive effects of Mr2034 and EKC was tested in the present study using the mu-selective antagonist $\beta$-FNA. A twenty-four hour pretreatment with both $\beta$-FNA and nor-BNI was no more effective at antagonizing the dose effect curves of morphine, BW-373U86, CI-977 or U69,593 than when either nor-BNI or $\beta$-FNA was given alone. However, the nor-BNI and $\beta$-FNA combination was considerably more effective antagonizing both Mr2034 and EKC than either antagonist was alone. In the case of Mr2034, both nor-BNI and $\beta$-FNA when given alone produced about a 4-fold increase in its $A_{50}$, but the combination of nor-BNI $+\beta$-FNA increased the $\mathrm{Mr} 2034 \mathrm{~A}_{50}$ by nearly 40 -fold, suggesting that the antinociceptive effects of Mr2034 were mediated, at least in part, by mu opioid receptors. $\beta$-FNA alone did not antagonize EKC, suggesting that ordinarily the antinociceptive effects of EKC are not mediated by mu receptors. However, pretreatment with both $\beta$-FNA and nor-BNI produced a bigger increase in the $\mathrm{A}_{50}$ for EKC than nor-BNI alone, suggesting that once kappa receptors are blocked by nor-BNI, mu-receptor activation may contribute to the antinociceptive effects of EKC.

In contrast to the low kappa selectivity of Mr2034 and EKC, the arylacetamides CI-977, U50,488 and U69,593 display high affinity for kappa receptors and high selectivity for kappa versus mu receptors (Lahti et al. 1985; Hunter et al. 1990). Bremazocine resembles the other benzomorphans $\mathrm{Mr} 2034$ and EKC in having high affinity for both kappa and mu receptors (Magnan et al. 1982; Hunter et al. 1990), but bremazocine has been reported to have very low efficacy at mu receptors and to function primarily as a mu antagonist (Von Voigtlander et al. 1982; Petrillo et al. 1984; Corbett and Kosterlitz 1986; Negus et al. 1990), indicating that bremazocine is selectively efficacious at kappa versus mu receptors. Thus, the compounds most sensitive to nor-BNI antagonism-CI-977, $\mathrm{U} 50,844, \mathrm{U} 69,593$ and bremazocine - are all characterized by either selective affinity for, or selective efficacy at, kappa versus mu receptors.

Coincident with the present study in mice, a study of similar design was conducted to examine the kappa antagonist effects of nor-BNI in the warm-water tail-withdrawal procedure in rhesus monkeys (Butelman et al. 1993), and it is of interest to compare the results of the two studies. In agreement with the present study, nor-BNI was shown to produce selective kappa antagonist effects for up to several weeks in rhesus monkeys. However, the sensitivity of various kappa agonists to antagonism by norBNI in mice differed markedly in rhesus monkeys. In the mice, as discussed above, nor-BNI was an effective antagonist of all kappa agonists tested, and most effective against bremazocine. Conversely, in the monkeys norBNI was an effective antagonist of U50,488 and U69,593, producing a half-log or greater shift in their dose-effect curves, but this same dose had no effect on the dose-effect curves for CI-977, bremazocine, EKC or Mr2033 (the racemate of $\mathrm{Mr} 2034$ ). Thus, whereas differential antagonism by nor-BNI of different kappa agonists in mice can be attributed largely to the potential for these compounds to act as mu agonists, the differential antagonism of different kappa agonists in rhesus monkeys cannot be so readily explained. The conclusion drawn from the experiments in monkeys was that different kappa agonists produced their antinociceptive effects by acting on different kappa receptor subtypes, and that nor-BNI distinguished between 
these subtypes. The finding that the profile of antagonist activity by nor-BNI differed in mice and rhesus monkeys is consistent with observations of dramatic species differences in kappa receptor binding (Robson et al. 1985; Mansour et al. 1988; Sharif et al. 1990). For example, it has been reported that both the relative proportion of kappa receptors to $\mathrm{mu}$ and delta receptors and the absolute density of kappa receptors are much less in mice and rats than in several other mammalian species, including humans (Mansour et al. 1988).

In summary, the present study found that nor-BNI produced long-lasting and selective kappa antagonist effects in mice. Furthermore, the present study identified differences in the sensitivity of six kappa agonists to antagonism by nor-BNI. All kappa agonists tested were significantly antagonized by lower doses of nor-BNI, indicating that at least some component of the effect of each of these agonists was mediated by pharmacologically similar, nor-BNI-sensitive kappa opioid receptors. However, these kappa agonists were markedly different in their sensitivity to higher doses of nor-BNI. This finding, together with results of the antagonism studies with $\beta$-FNA, suggests that in mice, the differential effects of nor-BNI on kappa agonists is based on the efficacy of the agonist at non-kappa (probably $\mathrm{mu}$ ) sites rather than on the selectivity of nor-BNI for subtypes of the kappa receptor.

\section{References}

Birch PJ, Hayes AG, Sheehan MJ, Tyres MB (1987) Norbinaltorphimine: antagonist profile at $\kappa$ opoid receptors. Eur J Pharmacol 144:405-408

Butelman ER, Negus SS, Ai Y, deCosta BR, Woods JH (1993) Kappa opioid antagonist effects of systemically administered nor-binaltorphimine in a thermal antinociception assay in rhesus monkeys. J Pharmacol Exp Ther 267: 1269-1276

Chang K-J, Rigdon GC, Howard JL, McNutt RW (1993) A novel, potent and selective non-peptidic $\delta$-opioid receptor agonist $\mathbf{B W}$ 373U96. J Pharmacol Exp Ther 267:852-857

Clark JA, Liu L, Price M, Hersh B, Edelson M, Pasternak GW (1989) Kappa opiate receptor multiplicity: evidence for two U50,488-sensitive $\kappa_{1}$ subtypes and a novel $\kappa_{3}$ subtype. J Pharmacol Exp Ther 251:461-468

Comer SD (1992) BW 373U86: Behavioral pharmacology of a putative non-peptide, systemically-active delta opioid agonist. PhD Thesis, University of Michigan, USA

Cooper SJ, Sanger DJ (1984) Endorphinergic mechanisms in food, salt and water intake: an overview. Appetite $5: 1-6$

Cooper SJ, Jackson A, Kirkham TC (1985) Endorphins and food intake: kappa opioid receptor agonists and hyperphagia. Pharmacol Biochem Behav 23:889-901

Corbett AD, Kosterlitz HW (1986) Bremazocine is an agonist at $\kappa$-opiate receptors and an antagonist at $\mu$-opioid receptors in guinea-pig myenteric plexus. Br J Pharmacol 89:245-249

Devlin T, Shoemaker WJ (1990) Characterization of kappa opioid binding using dynorphin $A_{1-13}$ and $U 69,593$ in the rat brain. J Pharmacol Exp Ther 253:749-759

Endoh T, Matsuura H, Tanaka C, Nagase H (1992) Nor-binaltorphimine: a potent and selective $\kappa$-opioid receptor antagonist with long-lasting activity in vivo. Arch Int Pharmacodyn. $316: 30-42$

Hayes AG, Sheehan MJ, Tyers MB (1987a) Differential sensitivity of models of antinociception in the rat, mouse and guinea-pig to $\mu$ and $\kappa$-opioid receptor agonists. Br J Pharmacol 91:823-832
Hayes AG, Skingle M. Tyers MB (1987b) Evaluation of the receptor selectivities of opioid drugs by investigating the block of their effect on urine output by $\beta$-funaltrexamine. J Pharmacol Exp Ther 240:984-988

Hein DW, Young AM, Herling S, Woods JH (1981) Pharmacological analysis of the discriminative stimulus characteristics of ethylketazocine in the rhesus monkey. J Pharmacol Exp Ther 218:7-15

Horan P, de Costa BR, Rice KC, Porreca F (1991) Differential antagonism of $\mathrm{U} 69,593$ - and bremazocine-induced antinociception by (-)-UPHIT: evidence of kappa opioid receptor multiplicity in mice. J Pharmacol Exp Ther 257:1154-1161

Horan P. Taylor J, Yamamura HI, Porreca F (1992) Extremely longlasting antagonistic actions of nor-binaltorphimine (nor-BNI) in the mouse tail-flick test. J Pharmacol Exp Ther 260:1237-1243

Hunter JC, Leighton GE, Meecham KG, Boyle SJ, Horwell DC, Rees DC, Hughs J (1990) CI-977, a novel and selective agonist for the $\kappa$-opioid receptor. Br J Pharmacol 101:183-189

Iyengar S, Kim HS, Wood PL (1986) Effects of kappa opiate agonists on neurochemical and neuroendocrine indices: evidence for kappa receptor subtypes. Life Sci 39:637-644

Jiang Q, Takemori AE, Sultana M, Portoghese PS, Bowen WD, Mosberg HI, Porreca F (1991) Differential antagonism of opioid delta antinociception by $\left[\mathrm{D}-\mathrm{Ala}^{2}, \mathrm{Leu}^{5}, \mathrm{Cys}^{6}\right]$ enkephalin and naltrindole $5^{\prime}$-isothiocyanate: evidence for delta receptor subtypes. I Pharmacol Exp Ther 257:1069-1075

Jones DNC, Holtzman SG (1992) Long term $\kappa$-opioid receptor blockade following nor-binaltorphimine. Eur $\mathrm{I}$ Pharmacol $215: 345-348$

Koster R, Anderson M, deBeer EJ (1959) Acetic acid for analgesic screening. Fed Proc 18:412

Lahti RA, Mickekson MM, McCall JM, Von Voigtlander PF (1985) $\left[{ }^{3} \mathrm{H}\right]-\mathrm{U}-69593$ a highly selective ligand for the opioid $k$ receptor. Eur J Pharmacol 109:281-284

Leander JD (1984) Kappa opioid agonists and antagonists: effects on drinking and urinary output. Appetite 5:7-14

Lord JAH, Waterfield AA, Hughs J, Kosteritz HW (1977) Endogenous opioid peptides: multiple agonists and receptors. Nature 267:495-499

Magnan J, Paterson SJ, Tavani A, Kosterlitz HW (1982) The binding spectrum of narcotic analgesic drugs with different agonist and antagonist properties. Naunyn-Schmiedeberg's Arch Pharmacol 319:197-205

Mansour A, Khachaturian H, Lewis ME, Akil H, Watson SJ (1988) Anatomy of CNS opioid receptors. Trends Neurosci $11: 308-314$

Martin WR, Eades CG, Thompson JA, Huppler RE, Gilbert PE (1976) The effects of morphine-and nalorphine-like drugs in the nondependent and morphine-dependent chronic spinal dog. J Pharmacol Exp Ther 197:517-532

Merz H, Stockhaus K, Wick H (1975) Stereoisomeric 5,9-dimethyl2'-hydroxy-2-tetrahydrofurfuryl-6,7-benzomorphans, strong analgesics with non-morphine-like action profiles. J Med Chem 18:996-1000

Negus SS, Picker MJ, Dykstra LA (1990) Interactions between mu and kappa opioid agonists in the rat drug discrimination procedure. Psychopharmacology 102:465-473

Pasternak GW (1986) Multiple mu opiate receptors: biochemical and pharmacological evidence for multiplicity. Biochem Pharmacol 35:361-364

Petrillo P, Gambino MC, Tavini A (1984) Bremazocine induces antinociception, but prevents opioid-induced constipation and catatonia in rats and precipitates withdrawal in morphine-dependent rats. Life Sci 35:917-927

Portoghese PS, Larson DL, Sayre LM, Fries DS, Takemori AE (1980) A novel opioid receptor site alkylating agent with irreversible narcotic antagonistic and reversible agonistic activities. J. Med Chem 24:233-234

Portoghese PS, Lipkowski AW, Takemori AE (1987) Binaltorphimine and nor-binaltorphimine, potent and selective $\kappa$-opioid receptor antagonists. Life Sci 40:1287-1292 
Portoghese PS, Sultana M. Takemori AE (1988) Naltrindole, a highly selective and potent non-peptide $\delta$ opioid receptor antagonist. Eur J Pharmacol 146:185-186

Robson LE, Gillan MGC, Kosterlitz HW (1985) Species differences in the concentrations and distributions of opioid binding sites. Eur J Pharmacol 112:65-71

Romer D, Buscher H, Hill RC, Maurer R, Petcher TJ, Welle HBA, Bakel HCCK, Akkerman AM (1980) Bremazocine: a potent, long-acting opiate kappa antagonist. Life Sci 27:971-978

Rothman RB, Bykov V, Reid A, DeCosta BR, Newman A-H, Jacobson AE, Rice KC (1988) A brief study of the selectivity of norbinaltorphimine, $(-)$-cyclofoxy, and $(+)$-cyclofoxy among opioid receptor subtypes in vitro. Neuropeptides 12:181-187

Rothman RB, Bykov V, DeCosta BR, Jacobson AE, Rice KC, Brady LS (1990) Interaction of endogenous opioid peptides and other drugs with four kappa opioid binding sites in guinea peg brain. Peptides $11: 311-331$

Rothman RB, Bykov V, Mahboubi A. Long JB, Jiang Q, Porreca F, De Costa BR, Jacobson AE, Rice KC, Holaday JW (1991) Interaction of $\beta$-funaltrexamine with $\left[{ }^{3} \mathrm{H}\right]$ cyclofoxy binding in rat brain: further evidence that $\beta$-FNA alkylates the opioid receptor complex. Synapse $8: 86-99$

Schmauss C, Yaksh TL (1984) In vivo studies on spinal opiate receptor systems mediating antinociception. II. Pharmacological profiles suggesting a differential association of $\mathrm{mu}$, delta and kappa receptors with visceral chemical and cutaneous thermal stimuli in the rat. J Pharmacol Exp Ther 228:1-12

Sharif NA, Durie E, Michel AD, Whiting RL (1990) Dog cerebral cortex contians $\mu, \partial-$ and $\kappa-$-opioid receptors at different densities: apparent lack of evidence for subtypes of the $\kappa$-receptor using selective radioligands. Brain Res 510:108-114
Sofuoglu M, Portoghese PS, Takemori AE (1991) Differential antagonism of delta opioid agonists by naltrindole and its benzofuran analog (NTB) in mice: evidence for deltra opioid receptor subtypes. J Pharmacol Exp Ther 257: 676-680

Takemori AE, Ho BY, Naeseth JS, Portoghese PS (1988a) Norbinaltorphimine, a highly selective kappa-opioid antagonist in analgesic and receptor binding assays. J Pharmacol Exp Ther $246: 255-258$

Takemori AE, Schwartz MM, Portoghese PS (1988b) Suppression by nor-binaltorphimine of kappa opioid-mediated diuresis in rats. J Pharmacol Exp Ther 247:971-974

Tallarida RJ, Murray RB (1981) Manual of pharmacologic calculations with computer programs. Springer, New York

Von Voigtlander PF, Lewis RA (1982) U-50,488: a selective kappa opioid agonist: comparison to other reputed kappa agonists. Prog Neuropsychopharmacol Biol Psychiatry 6:467-470

Ward SJ, Portoghese PS, Takemori AE (1982) Pharmacological characterization in vivo of the novel opiate, $\beta$-funaltrexamine, J Pharmacol Exp Ther 220:494-498

Wood PL, Charleson SE, Lane D, Hudgin RL (1981) Multiple opiate receptors: differential binding of $\mu, \kappa$ and $\delta$ agonists. Neuropharmacology 20:1215-1220

Zimmerman DM, Leander JD, Reel JK, Hynes MD (1987) Use of $\beta$-funaltrexamine to determine mu opioid receptor involvement in the analgesic activity of various opioid ligands. $J$ Pharmacol Exp Ther 241:374-378

Zukin RS, Eghbali M, Olive D, Unterwald EM, Tempel A (1988) Characterization and visualization of rat and guinea pig brain $\kappa$ opioid receptors: evidence for $\kappa_{1}$ and $\kappa_{2}$ opioid receptors. Proc Natl Acad Sci USA $85: 4061-4065$ 